\title{
Construction of the Performance Evaluation System of State-owned Capital Investment Company
}

\author{
Hanxiong Xiao ${ }^{1, *}$, Jianhui Liao ${ }^{1, \mathrm{a}}$ and Xiaobin $\operatorname{Lin}^{1, \mathrm{~b}}$ \\ ${ }^{1}$ State Grid Energy Research Institute Co. Ltd, Beijing, China
}

\begin{abstract}
The functional differences between state-owned capital investment companies and production-oriented state-owned enterprises determine the need to reconstruct the performance evaluation system of state-owned capital specialized operation. Based on the goal of specialized operation of state-owned capital, this paper puts forward the ideas and principles of selecting performance indicators, and constructs the evaluation index system.
\end{abstract}

\section{Introduction}

Since the reform and opening up of state-owned enterprises, there are still a series of problems in the reform and development of state-owned enterprises. At the 19th National Congress of the Communist Party of China, it is proposed to improve the management system of all kinds of state-owned assets, reform the authorized management system of state-owned capital, promote the strengthening, optimization and expansion of state-owned capital, and effectively prevent the loss of state-owned assets. "The state owned assets supervision and Administration Commission of the State Council promotes the transformation of functions mainly by managing capital" clearly puts forward that the supervision of state-owned assets should accelerate the transformation from "managing enterprises" to "managing capital".

In this context, speeding up the reform of the authorized management system of state-owned capital and exploring effective reform ideas and paths have become an important content of the reform of state-owned enterprises and state-owned assets management system. The specialized operation of state-owned capital investment and operation companies will promote the all-round transformation of state-owned assets management functions, from the physical form of enterprise management to the value form of capital management and control; while the operation of state-owned enterprises will focus on the real economy and implement the separation of state-owned capital operation and state-owned enterprise operation. Capital operation does not create value, but divides industrial profits by optimizing resource allocation. Setting up a special operation platform to serve industrial operation and separating capital operation from industrial operation are conducive to the flexible use of various capital operation skills to enhance the liquidity of state-owned capital and improve the efficiency of resource allocation.

\section{Literature Review}

At present, there are relatively few literatures on the evaluation of the operation efficiency of state-owned capital investment companies, and the relevant scholars mainly focus on the evaluation of the operation efficiency of state-owned capital. In terms of the objectives and ideas of the construction of the evaluation system, the existing literature believes that the performance evaluation of state-owned capital operation needs to reflect the interests of the owner and the behavior of the manager at the same time, so as to achieve the purpose of state-owned capital appreciation and macroeconomic, but it should build a differentiated performance evaluation system ${ }^{[1][2]}$ (Institute of industry and economics, 2016; Huang Mingming, 2017). Wen Zongyu et al. (2018) pointed out that the performance evaluation of state-owned capital operation should be distinguished from the specialization of state-owned enterprises $^{[3]}$. Zhao Zhigang (2016) believes that the evaluation of state-owned capital operation should focus on the medium and long-term assessment, and the assessment indicators should be precise but few ${ }^{[4]}$. Zhong Wen's(2011) evaluation system includes financial performance, policy performance and social performance ${ }^{[5]}$. Li Jun et al. (2014) constructed the evaluation system from the six dimensions of return on assets, economic value added and investment value-added rate ${ }^{[6]}$. In terms of the selection of performance evaluation indicators, Tang Xianjie et al. (2007) constructed the performance evaluation system of state-owned capital operation through four dimensions of finance, market, internal operation and learning and growth $^{[7]}$. However, at present, the relevant research is still limited to the analysis of the enterprise itself, and

*Corresponding author e-mail: xiaohanxiong@sgeri.sgcc.com.cn,

aliaojianhui@sgeri.sgcc.com.cn, blinxiaobin@sgeri.sgcc.com.cn 
fails to achieve a higher level of analysis of the investors. This paper aims to break away from the existing thinking of enterprise based analysis, analyze the differences between state-owned capital investment companies and state-owned enterprises, and construct the performance evaluation system of state-owned capital operation companies from five dimensions.

\section{Dimensions of the Performance Evaluation System}

The first dimension is liquidity. The mission of state-owned capital investment company is to flexibly use various capital operation means, improve the liquidity of state-owned capital, and effectively adjust the layout of state-owned capital through big strides forward and backward. The state-owned capital investment company allocates the state-owned capital as a whole through specialized capital operation, and dynamically optimizes the industrial structure by relying on highly liquid capital, so as to make the capital layout adapt to the requirements of national policies and the mission of enterprises.

The second dimension is layout. According to the requirements, the layout of the state-owned economy should focus on the important industries, key fields and key infrastructure related to the national security, the lifeline of the national economy and the people's livelihood, and on the forward-looking strategic industries to promote the sustained and healthy development of the economy. The state-owned capital investment companies must also concentrate the controlled capital to some key fields specified by their mission through capital operation.

The third dimension is the ability to maintain and increase value. Maintaining and increasing the value of state-owned assets is the basic requirement of the state for state-owned asset managers, and it is also the inevitable requirement for safeguarding the rights and interests of state-owned economic owners. The specialized operation of state-owned capital must pay attention to maintaining and increasing the value on the premise of improving the industrial competitiveness, and fundamentally strengthen the ability of maintaining and increasing the value of state-owned capital by improving the industrial operation efficiency and overall competitiveness.

Fourth, social responsibility. As an important material and political foundation of socialism with Chinese characteristics, state-owned enterprises must earnestly fulfill their social responsibilities. As a special state-owned enterprise, state-owned capital investment company is no exception. On the one hand, state-owned capital investment companies fulfill their social responsibilities, on the other hand, they support and guide their subordinate enterprises to give back to the society.

Fifth, system reform. The reform of state-owned enterprises aims to form a modern enterprise system and market-oriented operation mechanism that are more in line with China's basic economic system and the requirements of the development of socialist market economy, and cultivate a number of state-owned backbone enterprises with innovation ability and international competitiveness. The state-owned capital investment company, as the shareholder and controlling party of state-owned enterprises, has the responsibility to actively promote the reform and development of its subordinate enterprises.

\section{Principles of Indicator Selection}

The basic principles of indicator selection are as follows:

Firstly, both qualitative and quantitative indicators should be emphasized. The responsibility of the state-owned capital investment company is to control and operate the state-owned capital in the form of value, which is basically financial. To a large extent, the performance of state-owned capital operation can be measured with clear financial indicators, which has quantifiable evaluation criteria. However, it is difficult to define the policy objectives of some state-owned capital investment with quantitative indicators. For example, enterprise system reform is also the goal pursued by state-owned enterprise investment companies, but the effect of reform is difficult to quantify. Such indicators are generally scored by experts.

Secondly, pay attention to differences. The state-owned capital investment company is a kind of state-owned enterprise which undertakes specific functions. To evaluate the operating performance of such enterprises, we must reflect the commonness of state-owned enterprises. At the same time, we should also pay attention to that the state-owned capital investment company does not operate the real industry and does not set foot in the specific business, which is distinct from other state-owned enterprises. We must pay attention to this particularity when we examine the state-owned capital investment companies.

\section{Determination of Indicators}

According to the basic principles of the selection of evaluation indicators, we selects indicators from five dimensions to build the performance evaluation system of state-owned capital investment companies.

Table 1. Indicators of the Performance Evaluation System of State-owned Capital Investment Company

\begin{tabular}{ccc}
\hline Dimension & Indicator & Weight \\
\hline Liquidity & Capitalization rate & $15 \%$ \\
& Total turnover & $10 \%$ \\
Layout & Concentration & $15 \%$ \\
& Innovation intensity & $10 \%$ \\
Ability to maintain & Value preservation and & $10 \%$ \\
and increase value & appreciation rate & Return on equity \\
Social & Ratio of public donation & $10 \%$ \\
Responsibility & expenditure & $15 \%$ \\
Reform & Reform condition of & $15 \%$ \\
& governing & \\
\hline
\end{tabular}




\subsection{Liquidity}

The capitalization rate of state-owned assets. This index is the core index reflecting the liquidity of state-owned capital, which is obtained by calculating the tradable proportion of the total assets managed by the company. The higher the degree of capitalization of state-owned assets, the more convenient the flow. The capitalization of state-owned assets can enlarge the value of state-owned capital and reflect the marketization level of state-owned capital operation.

Total turnover. This indicator is derived from the ratio of total transactions to total assets under management during the year. The higher the total turnover rate, the faster and stronger the liquidity of state-owned assets.

\subsection{Layout}

The concentration of state-owned capital. This index is derived from the ratio of the state-owned capital invested in the main business to the total state-owned capital managed by the investment company. State owned capital investment companies usually have special investment direction. The higher the concentration of state-owned capital, the higher the specialization of investment companies.

Innovation intensity of state-owned capital. This index is derived from the ratio of the equity of the technology-based enterprise held by the investment company to the total state-owned capital managed. The important function of the state-owned economy is to control the forward-looking and strategic industrial links. Therefore, the higher the index is, the better the function of the investment company will be.

\subsection{Ability to maintain and increase value}

Value preservation and appreciation rate. This is the core index to measure the ability of maintaining and increasing the value of state-owned capital. It is obtained by calculating the ratio of the net state-owned capital at the end of the year to the net state-owned capital at the beginning of the year. The higher the proportion is, the better the value preservation and appreciation of state-owned capital will be realized.

Return on equity. This is an important index to measure the proliferation of state-owned capital, which is obtained by calculating the total amount of dividends and assets under management of the investment company. The higher the rate of return, the higher the ability of preserving and increasing the value of state-owned assets.

\subsection{Social Responsibility}

The ratio of public donation expenditure. This is an important indicator to measure the social responsibility of state-owned capital, which is obtained by calculating the proportion between the public welfare donation expenditure (weighted by the proportion of participation in holding) and the total assets managed by the investment company. The higher the ratio, the better the performance of social responsibility.

\subsection{Reform}

According to the requirements for the reform of the corporate governance system of state-owned enterprises in the documents such as the board of directors, the professional manager system and other aspects, this paper reviews the reform of the corporate governance system of the investment companies participating in the holding enterprises, and uses the expert scoring method to score.

\subsection{Combination of Indicators}

After determining the specific indicators, we need to determine the weight of each indicator to make the final score possible. In this paper, according to the performance evaluation index system set, combined with expert advice, establish the weight of each level of indicators.

In the determination of the standard value, this paper uses the efficacy coefficient method to eliminate the dimension and calculate the standard score. The standardized score after treatment is between 0-100.

The calculation formula of positive index is as follows:

Minimum value $=($ actual index $) /($ maximum index $)$

The calculation formula of negative index is as follows:

Standardized value $=-($ actual value - minimum value $)$ / (maximum value - minimum value)

The performance score of each state-owned capital investment company is obtained by weighting and summarizing the standard scores of each evaluation index.

\section{Conclusions and Suggestions}

The ultimate purpose of performance evaluation of state-owned capital investment companies is to serve the further improvement of state-owned assets management level. We should judge the company's operation according to the overall evaluation results and the evaluation results of each single index, analyze and formulate improvement plans, form a closed loop of performance management, and fundamentally improve the ability of state-owned capital professional operation. The state-owned capital investment company can also find the deficiency of its own investment and operation level and support self-examination and self correction by implementing performance benchmarking with the state-owned capital investment company in this field and other fields.

For the state-owned assets regulatory agencies, performance evaluation is an important tool to improve the management and service ability of state-owned assets and enterprises. By evaluating the state-owned assets investment companies that perform the responsibilities of 
investors, the regulatory authorities can find the deficiencies in capital investment direction and capital operation level, and timely guide the investment companies to improve the investment level. Performance evaluation can also be used as the basis for regulators to inject and transfer out state-owned capital to investment companies, and guide the state-owned capital to optimize the allocation.

\section{Acknowledgments}

This work was financially supported by the science and technology project of the headquarters of State Grid Corporation of China, namely "Research on the Capital Operation Analysis Technology and Reform Mode of the Company under the New Situation of Reform". And I sincerely thank the colleagues for cooperating with me in writing this paper.

\section{References}

1. Institute of industrial economics, Chinese Academy of Social Sciences, joint research group of state owned investment company professional committee of China Investment Association. State owned capital investment and operation, Practice and exploration of state owned investment company. Beijing: economic management press, 2015: 60-65.

2. Huang M. Clarifying the functional boundaries of state owned capital investment and operation companies. China's national conditions and strength, 2017 (3): 30.

3. Zhao Z. Research on the reform and performance appraisal of state owned capital investment companies. Chinese chief accountant, 2016 (9): 46-48.

4. Wen Z, Song S. Reform logic and performance evaluation system reconstruction of state owned capital operation function separated from state owned enterprises. Journal of Beijing University of technology and industry (SOCIAL SCIENCE EDITION), 2018 (2): 10-17, 104.

5. Zhong W. Research on performance evaluation of state owned capital operation. Chengdu: Southwest University of Finance and economics, 2011.

6. Li J, Xiao J. Performance evaluation of state owned capital operating companies. China Economic and trade guide, 2014 (34): 64-66.

7. Tang X, Sun W. Research on performance evaluation of state owned capital operation. Heilongjiang foreign trade and economic cooperation, 2007 (1): 87-88,102. 